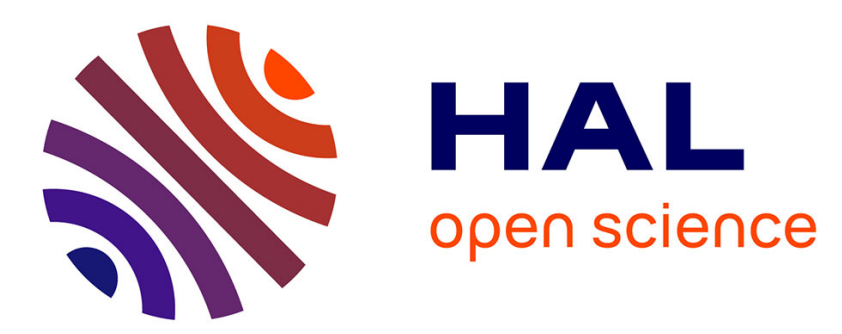

\title{
Structural characterization of humic substances from an acidic peat using thermochemolysis techniques
}

Cédric Guignard, Laurent Lemée, André Amblès

\section{To cite this version:}

Cédric Guignard, Laurent Lemée, André Amblès. Structural characterization of humic substances from an acidic peat using thermochemolysis techniques. Agronomie, 2000, 20 (5), pp.465-475. 10.1051/agro:2000142 . hal-00886060

\section{HAL Id: hal-00886060 https://hal.science/hal-00886060}

Submitted on 1 Jan 2000

HAL is a multi-disciplinary open access archive for the deposit and dissemination of scientific research documents, whether they are published or not. The documents may come from teaching and research institutions in France or abroad, or from public or private research centers.
L'archive ouverte pluridisciplinaire $\mathbf{H A L}$, est destinée au dépôt et à la diffusion de documents scientifiques de niveau recherche, publiés ou non, émanant des établissements d'enseignement et de recherche français ou étrangers, des laboratoires publics ou privés. 


\title{
Structural characterization of humic substances from an acidic peat using thermochemolysis techniques
}

\author{
Cédric Guignard, Laurent LemÉE, André AmBlÈs* \\ Laboratoire Synthèse et Réactivité des Substances Naturelles, UMR 6514 \\ Faculté des Sciences, 40 av. du Recteur Pineau, 86022 Poitiers, France
}

(Received 30 September 1999; revised 21 March 2000; accepted 11 April 2000)

\begin{abstract}
The general aim of the present work is a study of the insoluble organic matter (humic acids, humin) present in an acidic wetland, and more particularly lipidic parts involved in their chemical structure. Humic acids and humin from an acidic peat bog located at Brennilis (Sphagnum, pH 4.7) in Brittany (France) were characterised by spectroscopic properties (FT-IR and solid state ${ }^{13} \mathrm{C}$ NMR) of their functional groups. Analytical and preparative thermochemolysis (pyrolysis using tetraalkylammonium hydroxide) were also used to investigate humic substances. This technique yielded various ranges of hydrocarbons, fatty acid methyl esters and $\alpha, \omega$-dicarboxylic acid methyl esters. In both cases, pyrolysates contained high amounts of polar macromolecular components and aromatic products, mainly derived from lignin moieties, as syringic and p-coumaric units. Our results indicate that structural similarities exist between humic acids and humin in the Brennilis sample, but important structural differences can be pointed out by thermochemolysis.
\end{abstract}

\section{peat / thermochemolysis / humin / humic acids}

Résumé - Étude structurale de substances humiques d'une tourbe acide par thermochimiolyse. L'objectif général de ce travail est l'étude des formes insolubles de matière organique (humine, acides humiques) présentes dans une tourbe acide, et plus particulièrement de leur composante lipidique. Les principaux groupes fonctionnels des acides humiques et de l'humine de la tourbe acide de Brennilis (Sphaignes, pH 4,7) en Bretagne (France) ont été caractérisés par spectroscopie (FT-IR et RMN ${ }^{13} \mathrm{C}$ du solide). Plusieurs techniques de thermochimiolyse (pyrolyse en présence d'hydroxyde de tétraalkyl ammonium) analytique et préparative ont également été utilisées pour étudier les substances humiques. Ces techniques permettent d'isoler différentes séries d'hydrocarbures, d'esters méthyliques d'acides gras et d'esters $\alpha$, $\omega$-diméthyliques. Dans tous les cas, les pyrolysats contiennent une grande quantité de composés macromoléculaires et de produits aromatiques dérivés principalement de motifs ligneux, tels que les acides syringique et p-coumarique. Nos résultats indiquent que des similitudes existent entre les acides humiques et l'humine de l'échantillon de Brennilis, mais que des différences structurales importantes apparaissent par thermochimiolyse.

tourbe / thermochimiolyse / humine / acides humiques

Communicated by Isabelle Lamy

* Correspondence and reprints

andre.ambles@campus.univ-poitiers.fr 


\section{Introduction}

Humin and humic acids correspond often to the main part of soil organic matter, and are well-known for playing an important role in soil processes [32]. Despite their geochemical importance, the structure of humic substances remains largely unknown, as a consequence of their heterogeneity and their great complexity. In this work, the structure of humin and humic acids from an acidic peat was investigated by Fourier transform Infrared and solid state ${ }^{13} \mathrm{C}$ NMR spectroscopy, flash pyrolysis in the presence of tetramethylammonium hydroxyde (TMAH) or tetrapropylammonium hydroxyde (TPAH), and with a new preparative TMAH pyrolysis technique.

Pyrolysis with in situ methylation is a new, powerful technique for the structural analysis of macromolecules. This technique was firstly introduced by Challinor [5-7], and has been applied to several biopolymers [11,33] like lignin [8, 24], humic substances $[10,13,18,22,23,26,27,29,30,34]$ or whole soil organic matter [31]. The presence of TMAH avoids decarboxylation of aromatic acids and dehydration of alcohol moieties and, as a consequence, prevents the loss of important structural information. Most of the pyrolysis products also become more volatile and more easily analysable by Gas Chromatography-Mass Spectrometry (GC/MS). Moreover, this procedure of TMAH pyrolysis has been described by several authors $[9,18$, 22] as a thermally assisted chemolysis or thermochemolysis, rather than a classical pyrolysis. Recently, McKinney et al. [21] introduced an innovating thermochemolysis technique in sealed Pyrex $^{\circledR}$ tubes, at a subpyrolysis temperature of $300{ }^{\circ} \mathrm{C}$.

The preparative off-line thermochemolysis procedure used in this study has been developed in our laboratory $[15,16]$ to treat large quantities of humic material (up to $2 \mathrm{~g}$ ), in order to produce a high amount of pyrolysate that can therefore be separated by liquid chromatography prior to GC/MS analyses.

\section{Materials and methods}

\subsection{Samples and preparation of humic material}

The peat samples were collected in the Brennilis wetland (tourbière du Venec, Brittany, France), then freeze dried and sieved to $2 \mathrm{~mm}$ before analysis. After Soxhlet extraction of the free lipids with chloroform $(3 \times 24 \mathrm{~h})$, a part of fulvic acids and minerals were removed from the residue by treatment with $1 \mathrm{M} \mathrm{HCl}(10 \mathrm{~mL}$ per g). Humic and fulvic acids were then extracted by $0.1 \mathrm{M} \mathrm{NaOH}(10 \mathrm{~mL}$ per $\mathrm{g}$ ) under a nitrogen atmosphere. The alkaline treatment was reiterated 3 times to ensure total extraction. Humic acids were separated from fulvic acids by acidification to $\mathrm{pH} 1$ ( $6 \mathrm{M} \mathrm{HCl}$ solution) and centrifugation $(30 \mathrm{~min}, 7000 \times \mathrm{g})$. The alkaline-insoluble residue was Soxhlet extracted with dichloromethane $(2 \times 24 \mathrm{~h})$ to extract possibly adsorbed lipids. The final residue corresponded to a humin concentrate containing insoluble organic matter (humin) and the remaining mineral matter.

\subsection{Analytical thermochemolysis}

Humic samples (about $30 \mathrm{mg}$ in 5 elemental pyrolysis) were moistened with a TMAH (Aldrich) solution $(50 \% \mathrm{w} / \mathrm{w}$ in methanol) or a TPAH (Aldrich) solution (1 M in water) then introduced in a quartz tube before pyrolysis. The used pyrolysis device in a CDS Pyrobrobe 1000. The temperature was raised from $350{ }^{\circ} \mathrm{C}$ to $650{ }^{\circ} \mathrm{C}(10 \mathrm{~s}$ isothermally) at a rate of $5{ }^{\circ} \mathrm{C} \cdot \mathrm{ms}^{-1}$ under a helium flow. The products were directly analysed by GC/MS.

\subsection{Preparative thermochemolysis}

About $1 \mathrm{~g}$ of humic sample was placed in a ceramic boat and moistened with a TMAH/MeOH solution $(50 \% \mathrm{w} / \mathrm{w})$. The sample was dried under reduced pressure and introduced to a $60 \times 3 \mathrm{~cm}$ i.d. Pyrex $^{\circledR}$ tube. The tube was then placed in an oven heated at $400{ }^{\circ} \mathrm{C}$ for 1 hour. Thermochemolysis products were flushed out by a helium flow 
$\left(100 \mathrm{~mL} \cdot \mathrm{min}^{-1}\right)$ to two successive traps containing chloroform cooled at $-15^{\circ} \mathrm{C}$. Degradation products were obtained between 5 and $30 \mathrm{~min}$ after the tube was introduced in the oven. After evaporation of the solvent, pyrolysis products were separated by liquid chromatography on a $\mathrm{SiO}_{2}$ column. Mixtures of diethyl ether/petroleum ether of increasing polarity were used for elution.

\subsection{Analyses}

Elemental analyses were provided by combustion on a CE Instruments NA 2100 analyser.

Fourier transform-Infrared spectroscopy (FT-IR) was performed on a Nicolet 750 spectrometer, after sample incorporation in $\mathrm{KBr}$ pellets.

The solid state ${ }^{13} \mathrm{C}$ NMR spectrum was obtained with a Brucker MSL 400 spectrometer at $4 \mathrm{kHz}$ with magic angle spinning and cross-polarisation with a contact time of $1 \mathrm{~ms}$. The chemical shifts were measured downfield of tetramethylsilane (TMS).

Thermochemolysis products were analysed by capillary GC and GC/MS. The GC was a HewlettPackard model 6890 equipped with a split/splitless injector, a FID detector, a $30 \mathrm{~m} \times 320 \mu \mathrm{m} \times 0.25 \mu \mathrm{m}$ fused silica capillary column containing a $5 \%$ methyl phenyl siloxane phase (Hewlett Packard HP-5). The GC oven temperature was raised from $60{ }^{\circ} \mathrm{C}$ to $300{ }^{\circ} \mathrm{C}$ (20 min isothermally) at a rate of $5{ }^{\circ} \mathrm{C} \cdot \mathrm{min}^{-1}$.

The GC/MS analyses were carried out on a Varian model 3400 interfaced with a Finnigan Incos quadrupole mass spectrometer. The oven conditions were the same as for GC analyses. The structures of the various products were determined on the basis of their comparison with standards, of their mass spectra and by comparison with literature data.

\section{Results and discussion}

\subsection{General properties}

The studied soil sample was acidic (pH 4.7), it contained a high amount of organic matter (85 weight \%,
Table I. Amounts of the different forms of O.M.

\begin{tabular}{|c|c|c|c|c|}
\hline & Humin* & Humic Acids & Fulvic Acids** & Lipids \\
\hline $\mathrm{g} \cdot \mathrm{kg}^{-1}$ o.d. soil & 276 & 424 & 95 & 58 \\
\hline$\%$ of the T.O.M. & 32.3 & 49.8 & 11.1 & 6.8 \\
\hline
\end{tabular}

* As pure humin.

** By difference.

determined by combustion). The different forms of organic matter were separated using chemical selective extractions. The final residue or humin concentrate contained $83.74 \mathrm{wt} \%$ of organic matter (humin). As shown in Table I, humin and humic acids contributed respectively to $32.3 \mathrm{wt} \%$ and $49.8 \mathrm{wt} \%$ of the original organic matter, whereas lipids and fulvic acids represented a lower amount, $6.8 \mathrm{wt} \%$ and $11.1 \mathrm{wt} \%$, respectively.

The elemental composition of humin and humic acids is given in Table II. The value of the atomic $\mathrm{H} / \mathrm{C}$ ratio in humin and humic acids (1.63 and 1.38, respectively) indicates a highly aliphatic nature of these two types of organic matter.

FT-IR spectra of both humin concentrate and humic acids, presented in Figure 1, reveal a wide hydroxyl band from 2500 to $3500 \mathrm{~cm}^{-1}$, as well as polymethylenic bands between 2850 and $2925 \mathrm{~cm}^{-1}$. The band centred at $1652 \mathrm{~cm}^{-1}$ is due to $\mathrm{C}=\mathrm{C}$ overlapping the aromatic $\mathrm{C}=\mathrm{C}$ band $\left(\sim 1600 \mathrm{~cm}^{-1}\right)$, arising partly from lignin moieties. In the case of humic acids, the band near $1715 \mathrm{~cm}^{-1}$ corresponds to $\mathrm{C}=\mathrm{O}$ vibration from carbonyl or carboxyl (esters and acids) groups. The absorbance in the $1000-1100 \mathrm{~cm}^{-1}$ range may partly arise from $\mathrm{C}-\mathrm{O}$ vibration, but it can also originate from residual mineral matter, due to $\mathrm{Si}-\mathrm{O}$ vibration [20], especially in the case of the humin concentrate.

${ }^{13} \mathrm{C}$ NMR spectroscopy (Fig. 2) confirms the high aliphaticity of humin concentrate and humic acids:

Table II. Elemental composition (\%) of humin and humic acids.

\begin{tabular}{lcccccc}
\hline Fraction & $\mathrm{C}$ & $\mathrm{H}$ & $\mathrm{O} *$ & $\mathrm{~N}$ & $\mathrm{~S}$ & $\begin{array}{c}\text { Atomic } \\
\text { H/C ratio }\end{array}$ \\
\hline Humin (83.74) & 42.33 & 5.75 & 49.56 & 2.36 & 0.00 & 1.63 \\
Humic acids (94.40) & 47.05 & 5.40 & 43.97 & 3.53 & 0.05 & 1.38 \\
\hline
\end{tabular}

Numbers in brackets: percentage of organic matter, determined by combustion.

* By difference. 

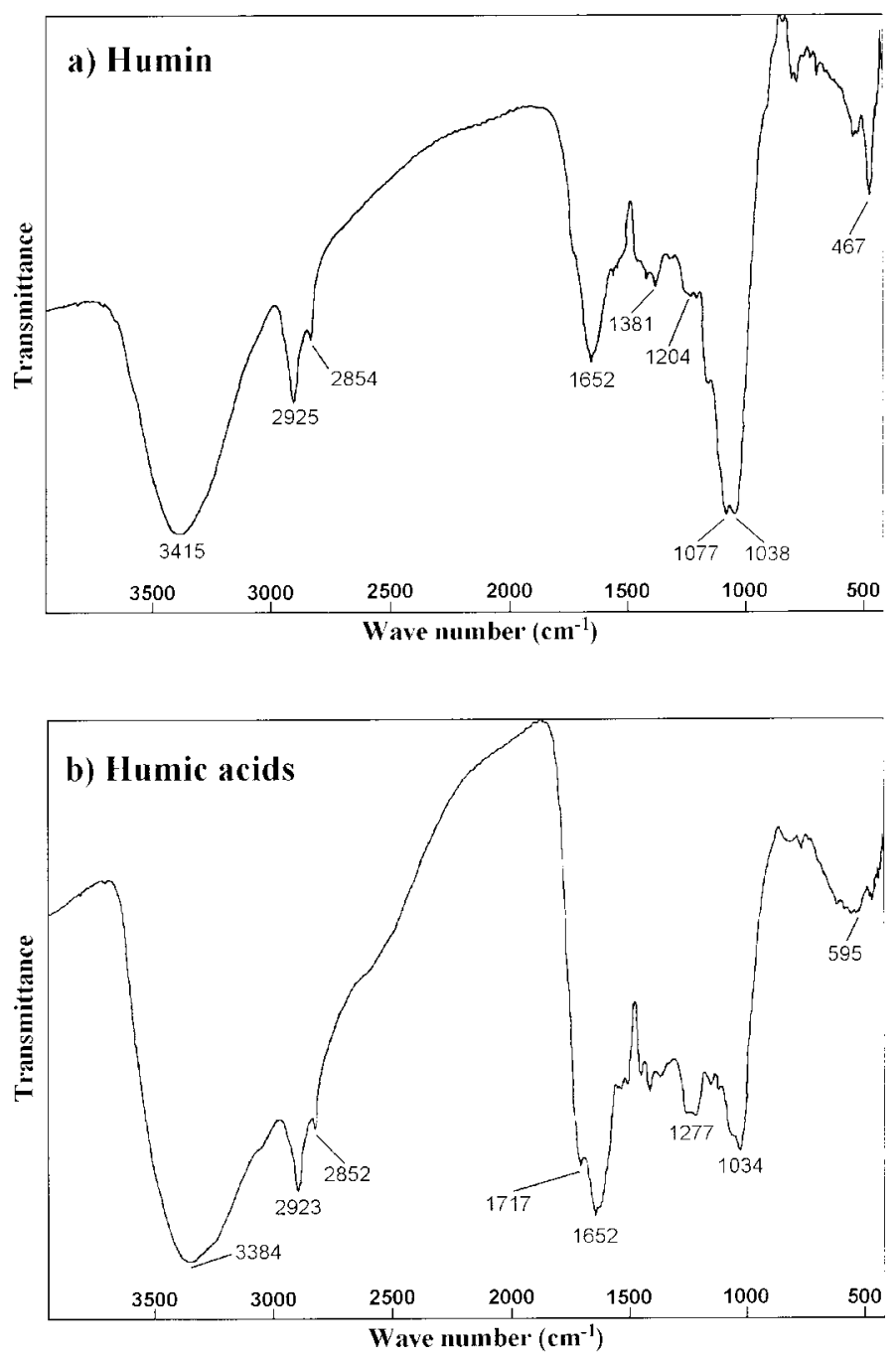

Figure 1. FT-IR spectra of humin and humic acids (wave numbers in $\mathrm{cm}^{-1}$ ). the important (humin; Fig. 2a) or prominent (humic acids; Fig. 2b) signal at $30 \mathrm{ppm}$ corresponds to paraffinic structures. Aromatic carbon signals (centred around $130 \mathrm{ppm}$ ) are present in both spectra, as well as phenolic carbons (150 ppm). The carboxyl signal at $172 \mathrm{ppm}$ suggests the occurrence of ester and acid groups in the structure. The signal centred at 74.5 ppm; (humin; Fig. 2a) or 71.7 ppm (humic acids; Fig. 2b), which is particularly intense in humin, is attributable to O-alkyl carbons from carbohydrate units of cellulose and hemicellulose [1] and probably to some alcohol groups. The peak at $104 \mathrm{ppm}$ in the humin spectrum corresponds to ketals and acetals from carbohydrates. Methoxyl carbons from lignin are detected at $56 \mathrm{ppm}$ [13] in the humic acids spectrum, and only as a shoulder in the case of humin. The observed signal centred at 212-213 ppm corresponds to carbonyl groups from ketones and possibly aldehydes. Nevertheless, a part of the signal at $212 \mathrm{ppm}$ and at $130 \mathrm{ppm}$ in humic acids (Fig. 2a) could be due to rotation sidebands of the signal at $172 \mathrm{ppm}$.

Finally, even if no precise quantitative determination is available, ${ }^{13} \mathrm{C}$ CP/MAS NMR spectroscopy indicates a wide aliphatic contribution in the studied humic substances, and points out the occurrence of carbohydrate and/or cellulose and hemicellulose moieties, particularly intense in 

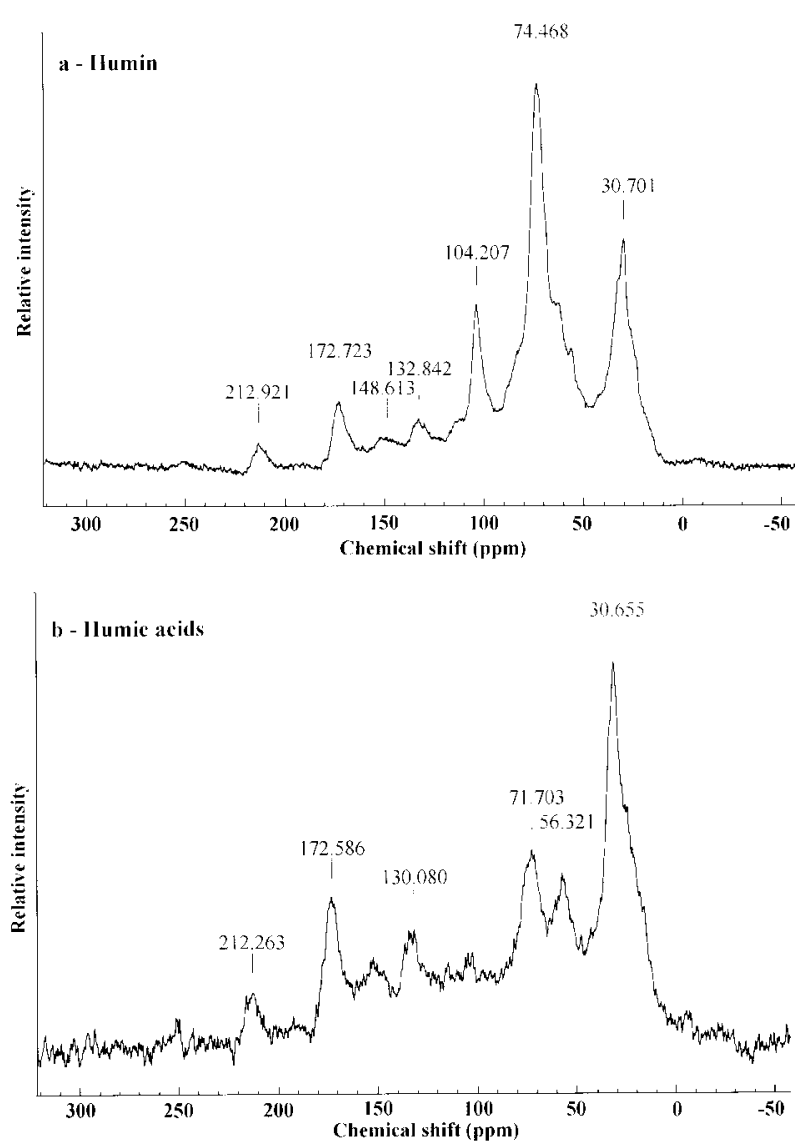

Figure 2. Solid state CP/MAS ${ }^{13} \mathrm{C}$ NMR spectra of humin concentrate and humic acids.

humin. Methoxyl carbons arising from lignin are more discernible in the case of humic acids.

\subsection{Flash thermochemolysis}

\subsubsection{TMAH pyrolysis}

Humin and humic acids were characterised by flash pyrolysis using tetramethylammonium hydroxide (TMAH). As a fact, the chromatogram of the pyrolysate appeared much more complex in humin than in humic acids (Fig. 3). In both cases, fatty acid methyl esters (FAMEs) arising from the transesterification of esters [14] were produced in the $\mathrm{C}_{14}-\mathrm{C}_{30}$ range (maxima at $\mathrm{C}_{16}$ and $\mathrm{C}_{24}$ ) with a strong even/odd predominance, the long $\mathrm{C}_{20}-\mathrm{C}_{30}$ members being more abundant in the case of humin. The unsaturated $\mathrm{C}_{18: 1}$ FAME is observed in both pyrolysates. Linear $\mathrm{C}_{15}-\mathrm{C}_{31}$ hydrocarbons (as alkene/alkane doublets) were released by humin treatment, whereas $n$-alkanes $\left(\mathrm{C}_{21}-\mathrm{C}_{27}\right)$ are detected as traces in the case of humic acids. Prist-1-ene and the isoprenoid $\mathrm{C}_{18}$ methylketone were also present in the products from humin.

$\alpha, \omega$-dicarboxylic acid methyl esters were identified in the $\mathrm{C}_{16}-\mathrm{C}_{26}$ range (maxima at $\mathrm{C}_{16}$ and $\mathrm{C}_{22}$ ) with a strong even/odd predominance in the humin pyrolysate. The short $\mathrm{C}_{8}$ and $\mathrm{C}_{9}$ members were also strongly present. In the case of humic acids, only the $\mathrm{C}_{16}$ (maximum) and $\mathrm{C}_{18}$ members were detected.

$\omega$-methoxy methyl esters represented major components in both pyrolysates. They were found in the $\mathrm{C}_{16}-\mathrm{C}_{28}$ range (maxima at $\mathrm{C}_{16}$ and $\mathrm{C}_{24}$ ), they were exclusively even carbon-numbered. The $\mathrm{C}_{16}$ member is largely prominent in the case of humic acids, whereas the long $\mathrm{C}_{20}-\mathrm{C}_{28}$ mode is higher in humin.

Pyrolysates contained also a wide range of aromatic compounds bearing one or more oxygenated group, like methoxyl or methylester groups, presenting consequently high similarities with lignin monomers. Factually, the observed methoxyl groups could arise either from lignin monomers, and/or hydroxyl groups methylated by TMAH. In order to differentiate these two origins, flash-pyrolysis using an alternative alkylating agent, tetrapropylammonium hydroxide (TPAH) has been applied.

\subsubsection{TPAH pyrolysis}

The aromatic compounds obtained by TPAH-thermochemolysis of humin and humic acids had the same structure as those obtained with TMAH, one or more methyl groups being replaced by propyl groups. The main aromatic compounds observed with TMAH and the corresponding TPAH products are reported in Table III.

As a fact, no methylester derivative was observed in the TPAH thermochemolysis products. Thus, the methylester (with TMAH) and propylester (with TPAH) groups originated exclusively from free or esterified carboxylic acids derivatised or transesterified by the alkylating agent. 

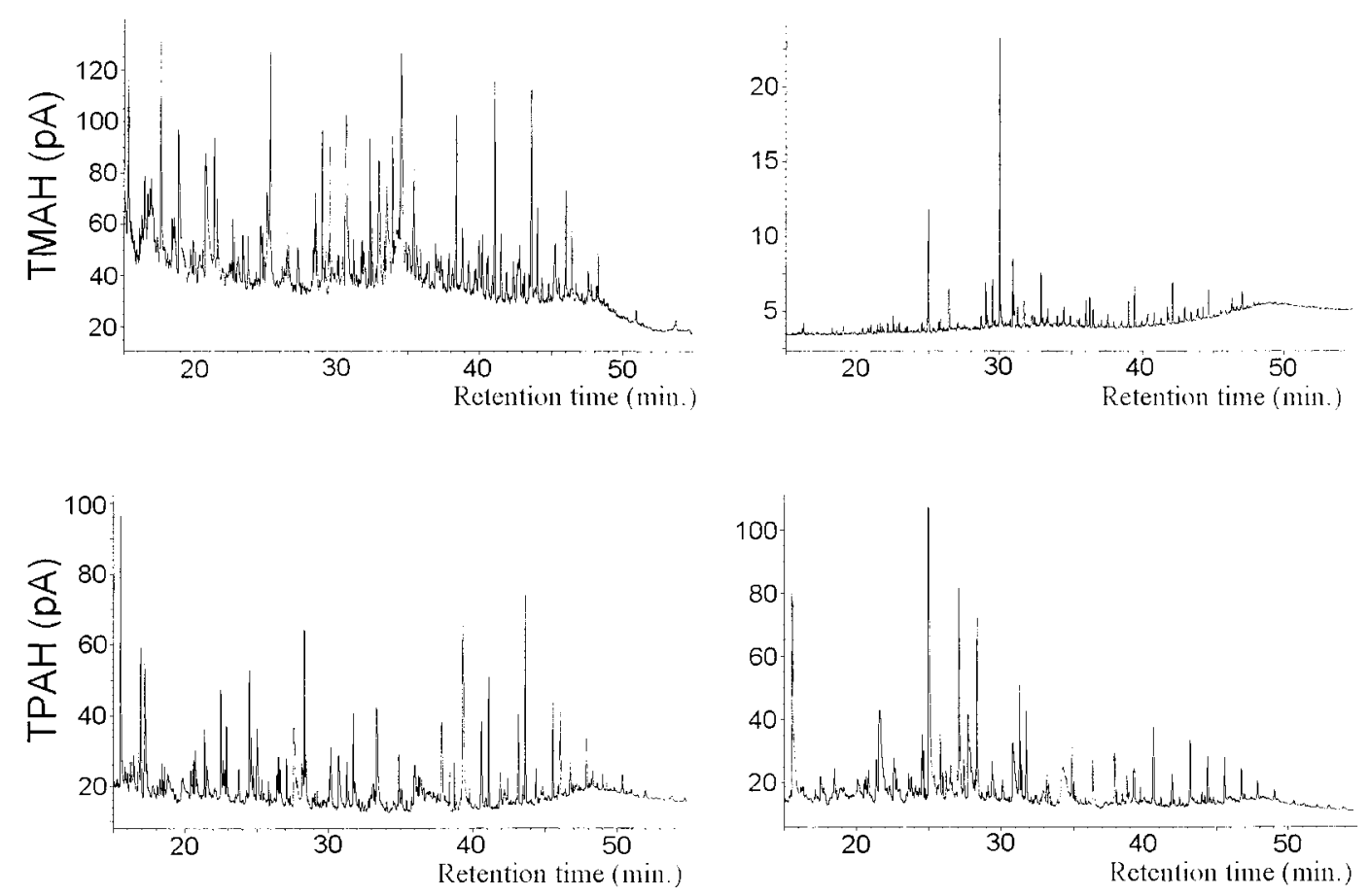

Figure 3. Pyrograms obtained by flash pyrolysis of humin (left) and humic acids (right).

As seen in Table III, some methoxyl groups are also present in the TPAH products. It is an indication that they were initially present in the matrix as methoxyl groups, and not as free or bounded hydroxyl groups. Conversely, methoxyl groups observed with TMAH and replaced by propyloxyl groups with TPAH correspond either to free hydroxyl groups or to hydroxyl groups bound to the matrix by ester groups.

Table III. Main aromatic compounds obtained by flash TMAH and TPAH thermochemolysis of humin and humic acids $\left(\mathrm{Me}=-\mathrm{CH}_{3} ; \mathrm{Pr}=-\left(\mathrm{CH}_{2}\right)_{2}-\mathrm{CH}_{3}\right)$.

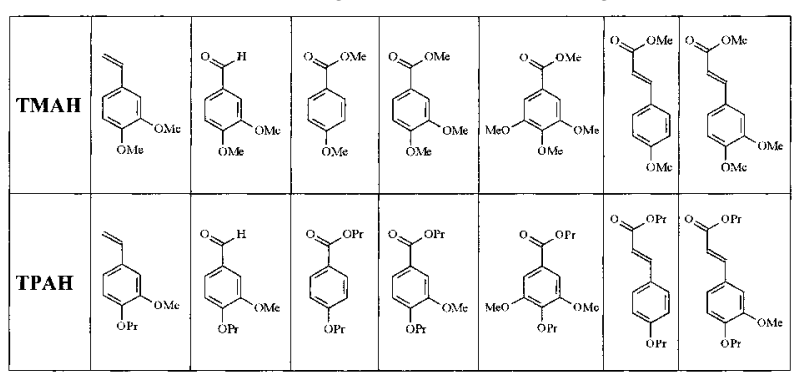

In addition to these aromatic compounds, $n$-alkene/alkane doublets are observed in the TPAH products, as well as propyl esters outcoming from fatty acids. The propyl esters present the same distribution as the FAMEs obtained with TMAH, confirming they were initially present as esterified acids in the macromolecular matrix.

\subsection{Preparative thermochemolysis}

\subsubsection{Quantitative results}

A quantity of about $1 \mathrm{~g}$ of humic acids and humin was submitted to preparative thermochemolysis. The yields given in Table IV indicate that humin is slightly more reactive than humic acids. The products were separated by liquid chromatography on a silica column which allows the quantification of each individual class of components. The amounts of the various kinds of products are reported in Table IV. At this level, some differences between humin and humic acids are observable, humin releasing higher amounts of hydrocarbons and $\alpha, \omega$ dicarboxylic acid methyl esters. 
Table IV. Quantitative results of thermochemolysis (in $\mathrm{mg} \cdot \mathrm{kg}^{-1}$ of humic O.M.).

\begin{tabular}{lrc}
\hline Fraction & Humin & Humic acids \\
\hline Yield* $^{*}$ & $21 \%$ & $16 \%$ \\
\hline Hydrocarbons & 11466 & 857 \\
Fatty acid methyl esters & 6454 & 5790 \\
Methoxyacid methyl esters & 767 & 437 \\
$\alpha, \omega$-dicarboxylic acid methyl esters & 3430 & 809 \\
Aldehydes & 794 & - \\
Ketones & 1549 & 95 \\
Aromatic compounds & 18510 & 14901 \\
Polar products & 86330 & 60686 \\
\hline
\end{tabular}

* Based on the total obtained products.

We can notice that the major part of the thermochemolysis products is constituted by polar compounds, which are not compliant with GC/MS analyses. These products are obviously highly macromolecular units from humic material.

\subsubsection{Detailed study of the thermochemolysis products}

Both humin and humic acids released linear hydrocarbons, as classical $n$-alkene/n-alkane doublets from $\mathrm{C}_{16}$ to $\mathrm{C}_{35}$, without any even/odd predominance. Unsaturated and saturated hydrocarbons can originate from the $\beta$-scission of radicals, but alk-1-enes can also derive from the decarboxylation of acids or the dehydration of alcohols. Actually, even if such secondary reactions are minimized in the presence of TMAH, it cannot entirely be prevented. The thermal degradation of esters is also known to generate alkanes (from the acid moiety) and alkene (from the alcohol part). Prist-1-ene and prist-2-ene were identified in substantial amounts, manifestly deriving from ether-bound phytol or tocopherol [16].

The presence of various hopanoid hydrocarbons with $17 \beta(\mathrm{H}), 21 \beta(\mathrm{H})$ configuration (derived from bacteriohopanetetrol) was observed, ranging from $\mathrm{C}_{27}$ to $\mathrm{C}_{31}$. The main compounds are the $\mathrm{C}_{27}, \mathrm{C}_{29}$ hopenes and the $\mathrm{C}_{27}$ hopane. 24-ethyl-cholesta-3,5diene was also detected as traces. These polycyclic compounds were certainly bound to the macromolecular matrix via ether or ester linkage.

Thermochemolysis of humin freed a wide range $\left(\mathrm{C}_{15}-\mathrm{C}_{33}\right)$ of linear methylketones (Fig. 4), with a marked odd/even carbon number predominance, in addition to an abundant $\mathrm{C}_{18}$ isoprenoid methylketone $(6,10,14$-trimethylpentadecan-2-one). The origin of these compounds has not been clearly established. The presence of the $\mathrm{C}_{18}$ isoprenoid methylketone was reported in the pyrolysis products from chlorophylls and cyanobacteria, the later containing also a series of linear methylketones [28]. As a consequence, the observed methylketones could be pyrolysis products from plant and microbial organic matter. However, no phytene nor phytadiene were found in the pyrolysates to confirm this assumption. Several mechanisms $[12,17]$, involving ether or $\mathrm{C}-\mathrm{C}$ bond cleavage, can explain the formation of methylketones from alkyl chains bound to the matrix by ether group or from chains acting as substituent of the matrix and bearing an alcohol or a keto group.

Likewise, $\mathrm{C}_{17}$ and $\mathrm{C}_{19}$ aldehydes are produced by thermochemolysis of humin, as several branched and/or unsaturated isomers. Their origin could be explained by the same mechanisms as ketones but

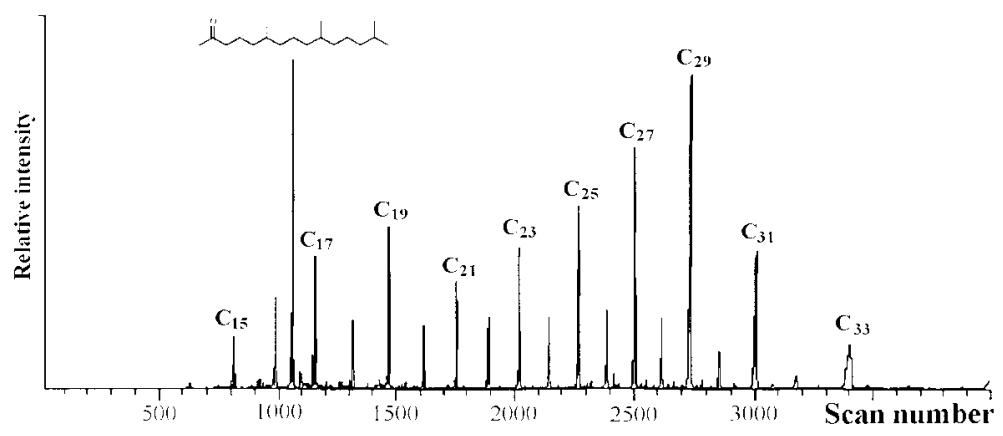

Figure 4. Distribution of methylketones released by thermochemolysis of humin $(\mathrm{m} / \mathrm{z}$ 58 selected ion fragmentogram). 


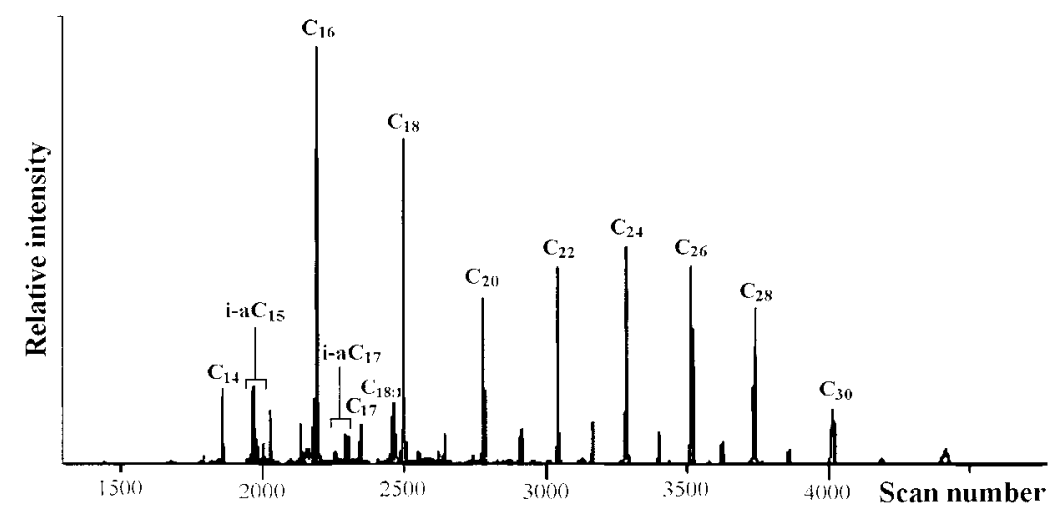

Figure 5. Distribution of fatty acids methyl esters released from humin by thermochemolysis (m/z 74 selected ion monitoring; $\mathrm{Cn}$ : linear; iCn: iso; $\mathrm{aCn}$ : anteiso). we have no direct evidence. Moreover, methylketones and aldehydes could be trapped in the macromolecular network, and then freed after breakage of the complex matrix.

Fatty acids released as methyl esters follow a quite similar distribution in samples of humin and humic acids (Fig. 5), with a strong even/odd carbon number predominance. The long $\mathrm{C}_{20}-\mathrm{C}_{32}$ mode, centred on $\mathrm{C}_{24}$, is representative of a plant input. The ubiquitous stearic and palmitic acids dominate the short $\mathrm{C}_{14}-\mathrm{C}_{18}$ mode. Unsaturated and/or branched isomers are also observed, specially $\mathrm{C}_{16: 1}$ and $\mathrm{C}_{18: 1}$. Iso- and anteiso $\mathrm{C}_{15}$ and $\mathrm{C}_{17}$ isomers, characteristic of a bacterial contribution $[3,4,25]$ are detected. The distribution of FAMEs released after preparative thermochemolysis of humic acids is almost the same as that from humin, except for the occurrence of higher $\mathrm{C}_{16: 1}$ and $\mathrm{C}_{18: 1}$ compounds.

The presence of $\alpha$ - and $\omega$-methoxy fatty acid methyl esters, derived from hydroxyacids, are observed in humic acids and humin pyrolysates. $\omega$-methoxy methyl esters, detected in the $\mathrm{C}_{16}-\mathrm{C}_{30}$ range, are exclusively even carbon-numbered, with maxima at $\mathrm{C}_{16}$ and $\mathrm{C}_{28}$. $\alpha$-methoxy methyl esters, from $\mathrm{C}_{22}$ to $\mathrm{C}_{26}$, were produced in minor amounts by humin treatment. Only the $\mathrm{C}_{24}$ and $\mathrm{C}_{26}$ members are detected as traces in the case of humic acids.

The obtained methoxyl group can derive from free hydroxyl, but it can also arise from the rupture of an ester (by transalkylation) or ether linkage. $\alpha, \omega$-dicarboxylic acid methyl esters were observed in the $\mathrm{C}_{14}-\mathrm{C}_{28}$ range, with a strong even/odd predominance. The $\mathrm{C}_{16}, \mathrm{C}_{18}$ and $\mathrm{C}_{22}$ members are prominent, as well as the unsaturated $\mathrm{C}_{16: 1}$ and $\mathrm{C}_{18: 1}$, especially in the case of humin (Fig. 6). $\alpha, \omega$-dicarboxylic acids can directly be inherited from higher plants [19]. They can also result from the bacterial terminal oxidation of fatty acids [2], followed by the incorporation to the humic matrix by esterification of both acid chemical groups. The observed double bond is maybe the consequence of carbon-heteroatom bond breakage, or more probably indicates the incorporation of unsaturated fatty acids, as oleic acid.

Aromatic compounds represent the main proportion of identifiable compounds in the thermochemolysis products of both humin and humic acids. They were the same as those observed by flash TMAH-pyrolysis (Fig. 7), vanillic, syringic and ferulic acids (as esters) being the most abundant in both humin and humic acids. As an evidence, these compounds indicate a high contribution of lignin moieties in the studied humic substances.

\section{Conclusions}

Infrared and NMR spectroscopy indicates that structural and functional similarities exist between 

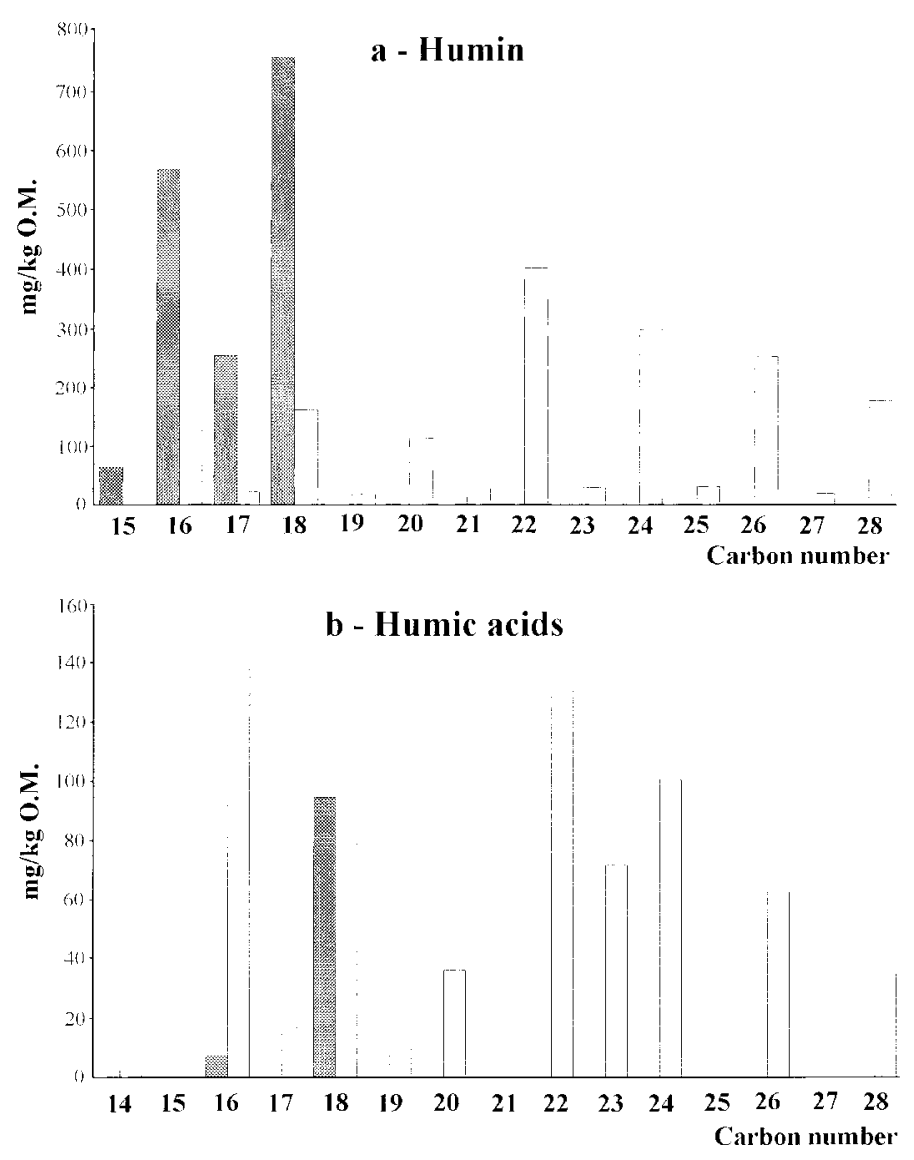

Figure 6. Distribution of dicarboxylic acids released as dimethyl esters by thermochemolysis of humin and humic acids ( $\square$ saturated; $\square$ unsaturated).

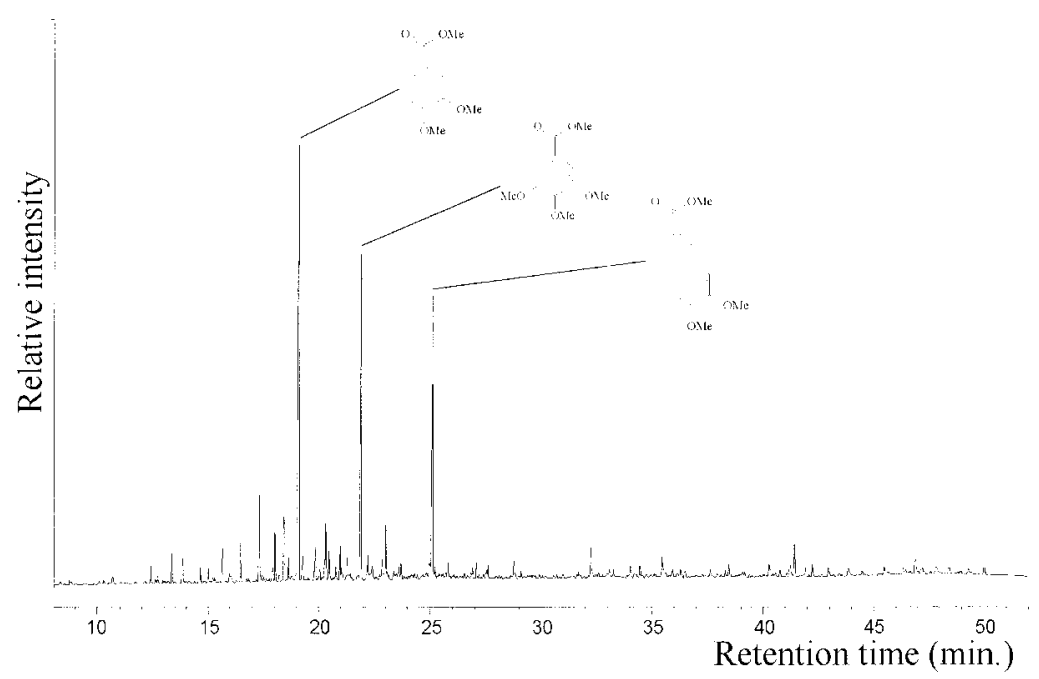

Figure 7. Chromatogram of the aromatic fraction obtained by thermochemolysis of the humic acids. 
humin and humic acids, but important differences can also be found in their lipidic constituents when using analytical TMAH and TPAH thermochemolysis, then preparative TMAH pyrolysis; humin releasing a wider range of products, with a higher chemical diversity. Moreover, lignin derivatives play an important role in the retention of more aliphatic products in both humin and humic acids. Furthermore, ester (and certainly ether) groups have proved to be essential in the reticulation of those macromolecules.

The preparative thermochemolysis is an efficient method in complement to spectroscopic analyses, and permits confirmation of the results obtained with flash pyrolysis techniques. It allows the treatment of greater quantities, and so permits the estimation of quantitative results and the detection of trace compounds. However, these results have to be confirmed by selective chemical degradations, the mechanisms occurring during thermochemolysis being insufficiently known at the moment.

Acknowledgements: This work was supported by the Centre National de la Recherche Scientifique (CNRS) and by the French Ministère de l'Éducation Nationale de la Recherche et de la Technologie (MENRT). The authors are grateful to Dr. C. Largeau and Dr. S. Derenne, École Nationale Supérieure de Chimie de Paris, for CP/MAS NMR measurements.

\section{References}

[1] Almendros G., Guadalix M.E., Gonzalez-Vila F.J., Martin F., Preservation of aliphatic macromolecules in soil humins, Org. Geochem. 24 (1996) 651-659.

[2] Amblès A., Halim M., Jacquesy J.C., Vitorovic D., Ziyad M., Characterization of kerogen from Timahdit shale (Y-layer) based on multistage alkaline permanganate degradation, Fuel 73 (1994) 17-24.

[3] Boon J.J., De Leeuw J.W., Hoele J.V.D., Vosjan J.H., Significance of the taxonomic value of iso and anteiso monoenoic fatty acids and branched $\beta$-hydroxyacids in desulfovibrio-desulfuricans, J. Bacteriol. 129 (1977) 1183-1191.

[4] Boon J.J., De Leeuw J.W., Burlingame A.L., Organic geochemistry of Walvis bay diatomaceous ooze - III. Structural analysis of the monoenoic and polycyclic fatty acids, Geochim. Cosmochim. Acta 42 (1978) 631-644.
[5] Challinor J.M., A pyrolysis-derivatisation-gas chromatography technique for the structural elucidation of some synthetic polymers, J. Anal. Appl. Pyrol. 16 (1989) 323-333.

[6] Challinor J.M., Structure determination of alkyd resins by simultaneous pyrolysis methylation, J. Anal. Appl. Pyrol. 18 (1991) 233-244.

[7] Challinor J.M., The scope of pyrolysis methylation reactions, J. Anal. Appl. Pyrol. 20 (1991) 15-24.

[8] Clifford D.J., Carson D.M., McKinney D.E., Bortiatynski J.M., Hatcher P.G., A new rapid technique for the characterization of lignin in vascular plants: thermochemolysis with tetramethylammonium hydroxide (TMAH), Org. Geochem. 23 (1995) 169-175.

[9] De Leeuw J.W., Baas M., The behaviour of esters in the presence of tetramethylammonium salts at elevated temperatures; flash pyrolysis of flash chemolysis?, J. Anal. Appl. Pyrol. 26 (1993) 175-184.

[10] Del Rio J.C., Gonzalez-Vila F.J., Martin F., Verdejo T., Characterization of humic acids from lowrank coals by ${ }^{13} \mathrm{C}-\mathrm{NMR}$ and pyrolysis-methylation. Formation of benzenecarboxylic acid moieties during coalification process, Org. Geochem. 22 (1994) 885-891.

[11] Del Rio J.C., Martin F., Gonzalez-Vila F.J., Thermally assisted hydrolysis and alkylation as a novel pyrolytic approach for the structural characterization of natural biopolymers and geomacromolecules, Tr. Anal. Chem. 15 (1996) 70-79.

[12] Gobé V., Matière organique complexe du sol. Structure et rôle dans les processus d'humification du carbone xénobiotique, Ph.D. thesis, University of Poitiers, France, 1998.

[13] Gonzalez-Vila F.J., del Rio J.C., Martin F., Almendros G., Structural relationship between humic fractions from peat and lignites from the Miocene Granada Bassin, Fuel 73 (1994) 215-221.

[14] Gonzalez-Vila F.J., del Rio J.C., Martin F., Verdejo T., Pyrolytic alkylation-gas chromatographymass spectrometry of model polymers. Further insights into the mechanism and scope of the technique, J. Chrom. A 750 (1996) 155-160.

[15] Grasset L., Étude de l'humine et des acides humiques des sols : importance de la composante lipidique, Ph.D. thesis, University of Poitiers, France, 1997.

[16] Grasset L., Amblès A., Structural study of soil humic acids and humin using a new preparative thermochemolysis technique, J. Anal. Appl. Pyrol. 47 (1998) $1-12$. 
[17] Hartgers W.A., Sinninghe Damsté J.S., de Leeuw J.W., Curie-point pyrolysis of sodium salts of functionalized fatty acids, J. Anal. Appl. Pyrol. 34 (1995) 191-217.

[18] Hatcher P.G., Gary E.M., Larry W.D., Flash pyrolysis and in situ methylation of humic acids from soil, Org. Geochem. 21 (1994) 1081-1092.

[19] Kolattukudy P.E., Chemistry and biochemistry of Natural Waxes, Elsevier, Amsterdam, 1976.

[20] McCarthy P., Rice J.A., Spectroscopic methods (other than RMN) for determining functionality in humic substances, in: Aiken G.R., McKnight D.M., Wershaw R.L., McCarthy J. (Eds.), Humic Substances in Soils, Sediments and Water, Willey and Sons, New York, 1985, pp. 527-559.

[21] McKinney D.E., Catson D.M., Clifford D.J., Minard R.D., Hatcher P.G., Off-line thermochemolysis versus flash pyrolysis for the in situ methylation of lignin: is pyrolysis necessary?, J. Anal. Appl. Pyrol. 34 (1995) 41-46.

[22] Martin F., Gonzalez-Vila F.J., del Rio J.C., Verdejo T., Pyrolysis derivatization of humic substances. I: Pyrolysis of fulvic acids in the presence of tetramethylammonium hydroxide, J. Anal. Appl. Pyrol. 28 (1994) 71-80.

[23] Martin F., del Rio J.C., Gonzalez-Vila F.J., Vertejo T., Pyrolysis derivatization of humic substances. II: Pyrolysis of soil humic acids in the presence of tetramethylammonium hydroxide, J. Anal. Appl. Pyrol. 31 (1995) 75-83.

[24] Martin F., del Rio J.C., Gonzalez-Vila F.J., Verdejo T., Thermally assisted hydrolysis and alkylation of lignins in the presence of tetra-alkylammonium hydroxides, J. Anal. Appl. Pyrol. 35 (1995) 1-13.
[25] Perry J.J., Volkman J.K., Johns R.B., Bavor H.J. Jr., Fatty acids of bacterial origin in contemporary marine sediments, Geochim. Cosmochim. Acta 43 (1979) 1715-1725.

[26] Saiz-Jimenez C., Pyrolysis/methylation of soil fulvic acids: benzene carboxylic acids revisited, Environ. Sci. Technol. 28 (1994) 197-200.

[27] Saiz-Jimenez C., Analytical pyrolysis of humic substances: pitfalls, limitations, and possible solutions, Environ. Sci. Technol. 28 (1994) 1773-1780.

[28] Saiz-Jimenez C., Microbial melanins in stone monuments, Sci. Tot. Environ. 167 (1995) 273-286.

[29] Saiz-Jimenez C., Hermosin B., Ortega-Calvo J.J., Pyrolysis/methylation: a method for structural elucidation of the chemical nature of aquatic humic substances, Water Res. 27 (1993) 1693-1696.

[30] Saiz-Jimenez C., Ortega-Calvo J.J., Hermosin B., Conventional pyrolysis: a biased technique for providing structural information on humic substances? Naturwissenschaften 81 (1994) 28-29.

[31] Schulten H.R., Sorge C., Pyrolysis methylationmass spectrometry of whole soils, Eur. J. Soil Sci. 46 (1995) 567-579.

[32] Stevenson F.J., Humus Chemistry. Genesis, Composition, Reactions, Wiley, New York, 1982.

[33] Tegelaar E.W., de Leeuw J.W., Holloway P.J., Some mechanisms of flash pyrolysis of naturally occurring higher plant polyesters, J. Anal. Appl. Pyrol. 15 (1989) 289-295.

[34] Tegelaar E.W., de Leeuw J.W., Saiz-Jimenez C., Possible origin of aliphatic moieties in humic substances, Sci. Tot. Environ. 81/82 (1989) 1-17. 